\title{
Role of Imaging in Prostate Cancer
}

\author{
Hossein Jadvar, MD, PhD, MPH, MBA and \\ Associate Professor of Radiology and Biomedical Engineering, Director of Radiology Research, \\ Keck School of Medicine University of Southern California, 2250 Alcazar Street, CSC 102, Los \\ Angeles CA 90033, Tel: 323-442-1107, jadvar@usc.edu
}

Abass Alavi, MD, MD (Hon), PhD (Hon), DSc (Hon)

Professor, Department of Radiology, Division of Nuclear Medicine, Hospital of the University of Pennsylvania, 3400 Spruce Street, 1 Donner Building, Philadelphia PA 19104-4283, USA, Phone: + 1 215-662-3069, Fax: +1 215-349-5843, Email: Abass.Alavi@uphs.upenn.edu

Cancer diagnosis and therapy is undergoing rapid evolution from the current nonspecific diagnosis and treatment toward patient-specific approach to therapy. Imaging is central in this evolution by providing accurate information on the presence and extent of disease (1). Unprecedented developments in molecular imaging are paving the way for this new era of imaging-based cancer diagnosis and therapy. Various imaging modalities and methods may be best suited for different phases of the disease. It is best to understand the natural history of disease and its progression in order to tailor the imaging evaluation appropriately. In this chapter, we first present a brief overview of the natural history of prostate cancer before discussing the role of various imaging tools, including opportunities and challenges, for different clinical phases of this disease. In subsequent chapters we focus our attention to the role of positron emission tomography in the imaging evaluation of prostate cancer.

\section{Natural History of Prostate Cancer}

Prostate cancer is the most common cancer and the second leading cause of cancer death affecting men in the United States. In 2008, the estimated incidence of and deaths from this disease were 186,320 cases and 28,660 cases, respectively (2). Prostate cancer is a heterogeneous disease characterized by an overall long natural history in comparison to the other solid tumors with a wide spectrum of biological behavior that ranges between indolent and aggressive states (3-5).

Prostate specific antigen (PSA), a $34 \mathrm{kD}$ androgen-regulated exocrine serine protease that cleaves the prostate-derived protein "seminogelin" in the seminal fluid for the liquefaction of the semen, is produced by both the normal and the diseased prostate cells and can be measured in the serum as an "organ-specific marker" in two major isoforms of complexed to $\alpha 1$ antichymotrypsin and uncomplexed free PSA (6). Various PSA parameters that have been employed for monitoring include PSA density, PSA velocity, PSA half-life, PSA nadir, PSA doubling time, time to PSA elevation, age-specific PSA reference ranges, and free to total PSA ratio (7-9). Despite the utility of PSA as an "organ-specific marker", it is not ideal due to its non-specificity and low sensitivity. PSA should not be considered as a direct measure of tumor growth since the serum level is influenced by the volume of the benign epithelium, grade of carcinoma, inflammation, androgen levels, growth factors, and the extracellular matrix (10).

\footnotetext{
Publisher's Disclaimer: This is a PDF file of an unedited manuscript that has been accepted for publication. As a service to our customers we are providing this early version of the manuscript. The manuscript will undergo copyediting, typesetting, and review of the resulting proof before it is published in its final citable form. Please note that during the production process errors may be discovered which could affect the content, and all legal disclaimers that apply to the journal pertain.
} 
PSA may be undetectable or low in view of disseminated prostate cancer (11-13) and there is emerging data to suggest that various therapies may affect the PSA expression in a manner unrelated to the impact on tumor growth (14-16). Additionally, PSA is frequently a source of great anxiety ("PSA-itis") (17).

In the post-PSA era, most patients (about 92\%) present with locoregional disease while metastatic disease is the initial presentation in about $4 \%$ of patients with the remaining $4 \%$ classified as unknown (1). The corresponding 5-year relative survival rates are $100.0 \%$ for localized/regional and $31.7 \%$ for distant disease. Despite highly successful treatments for localized prostate cancer, approximately $40 \%$ of men will eventually (most within 10 years from primary treatment) experience a detectable rise in the serum PSA level (biochemical failure) suggesting that prostate cancer can metastasize relatively early in the course of the disease (18). A portion of men with increasing serum PSA level will develop locally recurrent disease and as many as two-thirds will have evidence of osseous metastatic involvement (1922). Patients at highest risk for bone metastases include men older than 65 years, those with high-grade high-stage neoplasms, those who fail primary curative therapies and those who develop PSA relapse after androgen deprivation therapy (23-25).

Pound et al documented the natural history of progression to metastatic disease and death after PSA elevation following radical prostatectomy and no adjuvant hormonal therapy (26). A detectable serum PSA level of at least $0.2 \mathrm{ng} / \mathrm{mL}$ was considered as evidence for biochemical recurrence. The actuarial metastasis-free survival for all men was $82 \%$ at 15 years after surgery. The median actuarial time to metastases was 8 years from the time of PSA relapse. Once men developed metastatic disease, the median survival time to death was 5 years. The time to biochemical progression, PSA doubling time, and Gleason score were predictive of the probability and time to the development of metastatic disease. The time interval from surgery to the appearance of metastatic disease was predictive of time until death. Development of hormone refractory metastatic disease is associated with substantially lower one-year survival of only $24 \%$ (27).

Androgens are essential for the development, growth and maintenance of the prostate. The effects of androgens are exerted via the nuclear androgen receptor (AR), which is a liganddependent (either testosterone or 5 $\alpha$-dihydrotestosterone) transcription activator involved in cellular proliferation and differentiation, and is present in all histological types of prostate tumors, in recurrent carcinoma, and in tumor metastases (28-31). Almost all patients respond favorably to androgen ablation but virtually all patients will relapse to an androgen-independent clinical state. The hormone-refractory state is believed to occur via bypassing or sensitizing the AR pathway. The factors involved may be AR mutation such that the receptor is either activated promiscuously or is activated in a ligand-independent manner. Other factors include amplification of coactivators, activation of oncogenes, and autocrine growth factor stimulation (31).

\section{Diagnostic Imaging Evaluation of Prostate Cancer}

Imaging evaluation of prostate cancer remains particularly challenging that is a reflection of the clinical heterogeneity of the disease (32-35). Initial imaging differential diagnosis may be made when suspected (e.g. high serum PSA level, abnormal digital rectal examination) with ultrasound and/or magnetic resonance imaging (MRI) using endorectal probes, contrast agents, and image-guided biopsies. Imaging also provides important information on local extent of disease and examines for potential regional and distant metastatic disease in high risk patients. The most optimal method for imaging evaluation of men with PSA relapse is unsettled but the goal of imaging is to determine if there is recurrence in the treated prostate bed or distant disease is present (or both). Current imaging tests, including ultrasound, computed tomography (CT), 
magnetic resonance imaging (MRI), bone scintigraphy, and In-111 capromab pendetide (Prostascint, Cytogen, Princeton, NJ) are not sufficiently accurate to detect local recurrence or metastatic disease in prostate cancer (36). Such determination, however, is critical since it impacts therapeutic management including consideration for salvage therapy for local recurrence and systemic treatment for metastatic disease.

Prostascint is a radiolabeled antibody targeted to the prostate-specific membrane antigen (PSMA), which is a glycoprotein expressed in both the benign and the neoplastic prostatic epithelial cells. It is up-regulated in hormone-resistant states and in metastatic disease (37, 38). Despite the relevance of PSMA in prostate cancer, Prostascint has limited predictive value in imaging the prostate fossa, particularly following radiation therapy, has low sensitivity for detecting osseous metastases, is technically demanding, and requires interpretation at sites with experience and expertise $(39,40)$.

Although bone scintigraphy can be useful in detecting osseous metastases, the false positive rate is high (41), and cannot detect soft tissue or lymph nodal involvement, which is quite prevalent with metastatic spread of this disease. Bone scintigraphy has limited sensitivity in detecting metastases when the serum PSA level is below $2 \mathrm{ng} / \mathrm{mL}$ and only best correlates at high PSA levels of $>16 \mathrm{ng} / \mathrm{mL}(42,43)$. Additionally, a "flare" phenomenon may be observed with the initiation of hormonal ablation and even chemotherapy in the setting of clinical and serologic improvement but worsening scan pattern (44). However, in those patients who do not fit into this clinical scenario, bone scan progression may be considered when there are larger lesions, new lesions, or a combination of larger lesions and new lesions (45). There have been some efforts in developing methods for quantification of bone scintigraphy in order to facilitate quantitative determination of the extent of osseous metastatic disease and changes associated with response to treatment (46-48). Quantitative bone scintigraphy may also have prognostic utility with the percentage of the positive area of bone metastases as an independent predictor of the disease death in patients with prostate cancer $(49,50)$. Moreover, CT has been shown to be useful for additional evaluation of suspected skeletal metastases following bone scintigraphy by characterizing the radiographic appearance of the lesions (51).

Newer imaging methods using lymphotropic superparamagnetic nanoparticles in conjunction with high-resolution MRI may also allow the detection of small and otherwise undetectable lymph-node metastases in patients with prostate cancer (52). However, the exact clinical utility of such diagnostic imaging approach in a diverse group of patients will still need to be determined.

The current availability of hybrid positron emission tomography-computed tomography (PETCT) imaging systems in conjunction with the most common PET radiotracer, [F-18]fluorodeoxyglucose (FDG) have paved the way for the precise localization of metabolic abnormalities and characterization of the metabolic activity of normal and abnormal structures, thereby increasing diagnostic confidence and reducing equivocal image interpretations. Clinical utility of FDG PET in oncology has included initial diagnosis, staging and restaging of cancer, detection of metastases, prediction and evaluation for therapy response, differentiation of post-therapy changes from residual or recurrent tumor, and prognostication. The clinical experience with PET and PET-CT in prostate cancer is expanding. In this issue of PET Clinics, we discuss the current use and emerging role of PET with FDG and other radiotracers in prostate cancer.

\section{References}

1. Benaron DA. The future of cancer imaging. Cancer Metastasis Rev 2002;21:45-78. [PubMed: 12400996] 
2. SEER: The Surveillance, Epidemiology, and End Results Program - based within the Surveillance Research Program (SRP) at the National Cancer Institute. 2008. (http://seer.cancer.gov/statfacts/html/prost.html)

3. Frank, IN.; Graham, S., Jr; Nabors, WL. Urologic and Male Genital Cancers. In: Holleb, AI.; Fink, DJ.; Murphy, GP., editors. Clinical Oncology. Atlanta: American Cancer Society; 1991. p. 280-283.

4. Kessler B, Albertsen P. The natural history of prostate cancer. Urol Clin North Am 2003;30:219-226. [PubMed: 12735499]

5. Small EJ. Prostate cancer: incidence, management and outcomes. Drugs Aging 1998;13:71-81. [PubMed: 9679210]

6. Lin DW, Noteboom JL, Blumenstein BA, et al. Serum percent free prostate-specific antigen in metastatic prostate cancer. Urology 1998;52:366-371. [PubMed: 9730445]

7. Ploch NR, Brawer MK. How to use prostate-specific antigen. Urology 1994;43(2 Suppl):27-35. [PubMed: 7509534]

8. Lukes M, Urban M, Zalesky M, et al. Prostate-specific antigen: current status. Folio Biol (Praha) 2001;47:41-49.

9. Boccon-Gibod, L. Facts and probabilities. Vol. 24. Presse Med; 1995. Prostate-specific antigen or PSA; p. 1471-1472.

10. Crawford ED, DeAntoni EP, Ross CA. The role of prostate-specific antigen in the chemoprevention of prostate cancer. J Cell Biochem Suppl 1996;25:149-155. [PubMed: 9027612]

11. Safa AA, Reese DM, Carter DM, et al. Undetectable serum prostate-specific antigen associated with metastatic prostate cancer: a case report and review of the literature. Am J Clin Oncol 1998;21:323326. [PubMed: 9708626]

12. Sella A, Konichezky M, Flex D, et al. Low PSA metastatic androgen-independent prostate cancer. Eur Urol 2000;38:250-254. [PubMed: 10940696]

13. Beardo P, Fernandez PL, Corral JM, et al. Undetectable prostate specific antigen in disseminated prostate cancer. J Urol 2001;166:993. [PubMed: 11490269]

14. Dreicer R. Metastatic prostate cancer: assessment of response to systemic therapy. Semin Urol Oncol 1997;15:28-32. [PubMed: 9050137]

15. Bauer KS, Figg WD, Hamilton JM, et al. A pharmacokinetically guided Phase II study of carboxyamido-triazole in androgen-independent prostate cancer. Clin Cancer Res 1999;5(9):23242329. [PubMed: 10499600]

16. Horti J, Dixon SC, Logothetis C, et al. Increased transcriptional activity of PSA in the presence of TNP-470, an angiogenesis inhibitor. Br J Cancer 1999;79:1588-1593. [PubMed: 10188911]

17. Lofters A, Juffs HG, Pond GR, et al. "PSA-itis": knowledge of serum prostate specific antigen and other causes of anxiety in men with metastatic prostate cancer. J Urol 2002;168(6):2516-2520. [PubMed: 12441952]

18. Dong JT, Rinker-Schaeffer CW, Ichikawa T, et al. Prostate cancer-biology of metastasis and its clinical implications. World J Urol 1996;14:182-189. [PubMed: 8806197]

19. Yu KK, Hawkins RA. The prostate: diagnostic evaluation of metastatic disease. Radiol Clin North Am 2000;38:139-157. [PubMed: 10664670]

20. Carroll P. Rising PSA after a radical treatment. Eur Urol; 40 Suppl 2001;2:9-16.

21. McMurtry CT, McMurtry JM. Metastatic prostate cancer: complications and treatment. J Am Geriatr Soc 2003;51:1136-1142. [PubMed: 12890079]

22. Timme TL, Satoh T, Tahir SA, et al. Therapeutic targets for metastatic prostate cancer. Curr Drug Targets 2003;4(3):251-261. [PubMed: 12643475]

23. De la Taille A, Vancherot F, Salomon L, et al. Hormone-refractory prostate cancer: a multi-step and multi-event process. Prostate Cancer prostatic Dis 2001;4:204-12. [PubMed: 12497019]

24. Carlin BI, Andriole GL. The natural history, skeletal complications, and management of bone metastases in patients with prostate carcinoma. Cancer 2000;88(12 Suppl):2989-2994. [PubMed: 10898342]

25. Herold DM, Hanlon AL, Movsas B, et al. Age-related prostate cancer metastases. Urology 1998;51:985-990. [PubMed: 9609637] 
26. Pound CR, Partin AW, Eisenberger MA, et al. Natural history of progression after PSA elevation following radical prostatectomy. JAMA 1999;281:1591-1597. [PubMed: 10235151]

27. Fossa SD, Dearnaley DP, Law M, et al. Prognostic factors in hormone-resistant progressing cancer of the prostate. Ann Oncol 1992;3:331-335. [PubMed: 1616886]

28. Trapman J, Brinkmann AO. The androgen receptor in prostate cancer. Pathol Res Pract 1996;192:752760. [PubMed: 8880876]

29. Culig Z, Hobisch A, Hittmair A, et al. Androgen receptor gene mutations in prostate cancer. Implications for disease progression and therapy. Drugs Aging 1997;10:50-58. [PubMed: 9111707]

30. Culig Z, Klocker H, Bartsch G, et al. Androgen receptors in prostate cancer. Endocr Relat Cancer 2002;9:155-170. [PubMed: 12237244]

31. Jenster G. The role of the androgen receptor in the development and progression of prostate cancer. Semin Oncol 1999;26:407-421. [PubMed: 10482183]

32. Yu KK, Hricak H. Imaging prostate cancer. Radiol Clin North Am 2000;38:59-85. [PubMed: 10664667]

33. Carey BM. Imaging for prostate cancer. Clin Oncol (R Coll Radiol) 2005;17:553-559. [PubMed: 16238143]

34. Oehr P, Bouchelouche K. Imaging of prostate cancer. Curr Opin Oncol 2007;19:259-264. [PubMed: 17414646]

35. Fuchsjager M, Shukla-Dave A, Akin O, et al. Prostate cancer imaging. Acta Radiol 2008;49:107120. [PubMed: 18210320]

36. Hricak H, Schoder H, Pucar D, et al. Advances in imaging in the postoperative patient with a rising prostate-specific antigen level. Semin Oncol 2003;30:616-634. [PubMed: 14571410]

37. Fair WR, Israeli RS, Heston WD. Prostate-specific membrane antigen. Prostate 1997;32:140-8. [PubMed: 9215402]

38. Elgamal AA, Holmes EH, Su SL, et al. Prostate-specific membrane antigen (PSMA): current benefits and future value. Semin Surg Oncol 2000;18:10-16. [PubMed: 10617892]

39. Haseman MK, Reed NL, Rosenthal SA. Monoclonal antibody imaging of occult prostate cancer in patients with elevated prostate-specific antigen. Positron emission tomography and biopsy correlation. Clin Nucl Med 1996;21(9):704-713. [PubMed: 8879871]

40. Haseman MK, Rosenthal SA, Polascik TJ. Capromab pendetide imaging of prostate cancer. Cancer Biother Radiopharm 2000;15(2):131-140. [PubMed: 10803318]

41. Dotan ZA. Bone imaging in prostate cancer. Nat Clin Prac Urol 2008;5:434-44.

42. Modoni S, Calo E, Nardella G, et al. PSA and bone scintigraphy. Int J Biol Markers 1997;12:158161. [PubMed: 9582605]

43. Lee CT, Oesterling JE. Using prostate-specific antigen to eliminate the staging radionuclide bone scan. Urol Clin North Am 1997;24:389-394. [PubMed: 9126236]

44. Coleman RE, Mashiter G, Whitaker KB, et al. Bone scan flare predicts successful systemic therapy for bone metastases. J Nucl Med 1988;29:1354-1359. [PubMed: 3261330]

45. Bubley GJ, Carducci M, Dahut W, et al. Eligibility and response guidelines for phase II clinical trials in androgen-independent prostate cancer: recommendations from the prostate-specific antigen working group. J Clin Oncol 1999;17:3461-3467. [PubMed: 10550143]

46. DeLuca SA, Castronovo FP, Rhea JT. The effects of chemotherapy on bony metastases as measured by quantitative skeletal imaging. Clin Nucl Med 1983;8:11-13. [PubMed: 6831814]

47. Drelichman A, Decker DA, Al-Sarraf M, et al. Computerized bone scan. A potentially useful technique to measure response in prostate carcinoma. Cancer 1984;53:1061-1065. [PubMed: 6229325]

48. Imbriaco M, Larson SM, Yeung HW, et al. A new parameter for measuring metastatic bone involvement by prostate cancer: the bone scan index. Clin Cancer Res 1998;4:1765-1772. [PubMed: 9676853]

49. Noguchi M, Kikuchi H, Ishibashi M, et al. Percentage of the positive area of bone metastasis is an independent predictor of disease death in advanced prostate cancer. Br J Cancer 2003;88(2):195201. [PubMed: 12610502] 
50. Yahara J, Noghuchi M, Noda S. Quantitative evaluation of bone metastases in patients with advanced prostate cancer during systemic treatment. BJU Int 2003;92:379-384. [PubMed: 12930424]

51. Rafii M, Firooznia H, Kramer E, et al. The role of computed tomography in evaluation of skeletal metastases. J Comput Tomogr 1988;12:19-24. [PubMed: 3349795]

52. Harisinghani MG, Barentsz JO, Hahn PF, et al. Noninvasive detection of clinically occult lymphnode metastases in prostate cancer. N Eng J Med 2003;348(25):2491-2499. 